\title{
IMPROVING THE APPROACH TO EFFICIENCY ASSESSMENT OF INVESTMENT PROJECTS IN THE ENERGY SECTOR
}

\author{
ANZHELIKA KARAEVA ${ }^{1}$, ELENA MAGARIL ${ }^{1}$ \& ELENA CRISTINA RADA ${ }^{2}$ \\ ${ }^{1}$ Department of Environmental Economics, Ural Federal University, Russia \\ ${ }^{2}$ Department of Theoretical and Applied Science, University of Insubria, Italy
}

\begin{abstract}
According to the annual world statistics, primary energy consumption demonstrated a steady growth over the past decade but in 2018, its average value was doubled. A rapid development of energy sector will not only lead to the growth of $\mathrm{CO}_{2}$ emissions and other negative consequences, but also to more intensive use of natural resources in the immediate future. Growing pressure on resources might give rise to a number of challenges in virtually all branches of human activity. The energy sector's impact on the environment is increasing at a high speed, which necessitates the efficiency assessment of investments in energy projects applying a system of technical, economic and environmental indicators. Nowadays, most of the energy projects comprise eco-friendly technological solutions that significantly decrease the use of natural resources but at the same time they might affect financial costs that dampen the attractiveness of investment projects at all. Despite that fact, the economic and environmental evaluation allows identifying the total exposure of the project in the long term and aids in measuring its multiplier effect on the region economy as lots of energy projects have a considerable innovative potential. The present study provides a system of environmental indicators that improves the efficiency assessment process of investment projects in the energy sector.
\end{abstract}

Keywords: energy sector, efficiency assessment, investment energy project, eco-efficiency.

\section{INTRODUCTION}

The rapid development of the world economy leads to the growth in the demand for energy. In the last decade, people and companies became more aware about the energy sector; they tried to be involved in its management in order to obtain benefits not only from the economic point of view but also from the environmental one [1]-[8]. Fast-growing China and India are prime examples of countries that are experiencing a sharp increase in energy consumption [9]-[12]. According to recent statistics, about $80 \%$ of the global growth of energy production occurs in developing countries, the contribution of China and India is estimated at $40-42 \%$ [13]. A decline in their economies' growth rates is not expected in the coming decades, which will cause an increase in primary energy consumption.

According to the basic scenarios, the global primary energy consumption may rise by 25 $35 \%$ relative to the level of 2016 by 2040 [13]. Moreover, the expected values of the level of demand for energy have been adjusted in a larger direction regarding the versions of forecasts made in the previous year.

Fig. 1 demonstrates the structure of global energy consumption by sector from 2016 to 2018. The growth of energy consumption is observed in all sectors of the economy, which leads to an increase in energy demand and production. Moreover, the lower rate of change in the fuel structure of energy production significantly increases the impact of the energy sector on the environment.

Despite the development of green energy options [15]-[17], the global energy consumption structure is dominated by traditional energy sources (Fig. 2), that entailed the accelerated depletion of fossil fuels and pollution of the environment by emissions of 


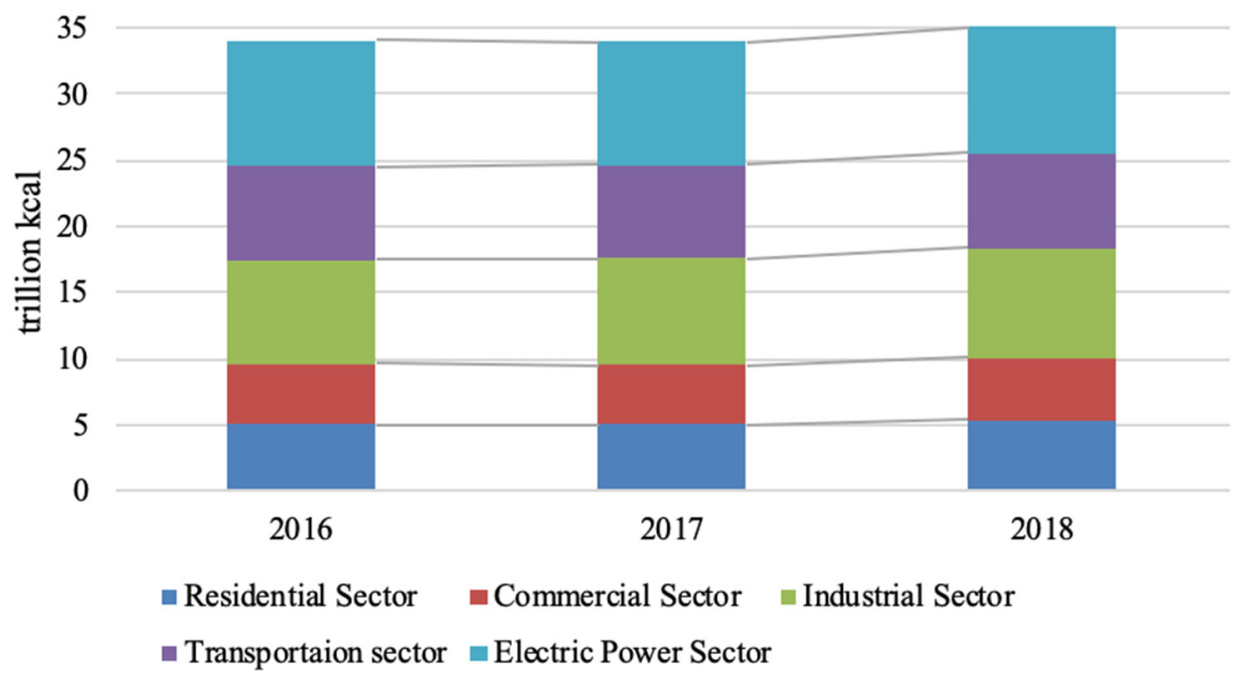

Figure 1: World energy consumption by sector. (Source: Calculated by the authors, using data from [14].)

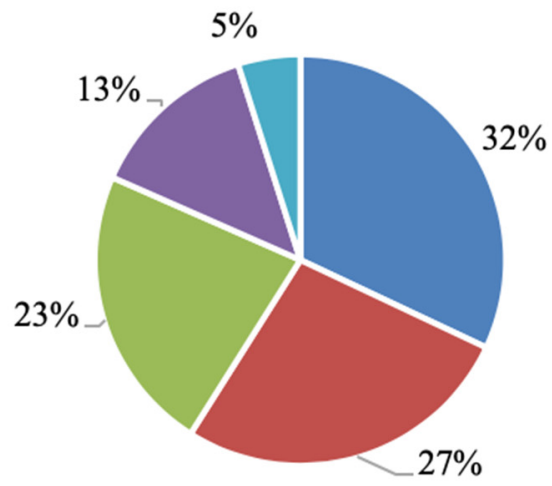

- Oil and Petroleum Products

- Solid Fossil Fuels

- Natural Gas

- Renewables and Biofuels

- Nuclear

Figure 2: Fuel shares in the energy sector in 2018. (Source: Calculated by the authors, using data from [18].)

combustion products. Coal and natural gas account for more than $64 \%$ of the global energy consumption, while renewable energy consumption does not exceed 9\% [13].

The structures of global energy consumption by electricity plants, CHP plants and heat plants are presented in Fig. 3.

The structure of fuel consumption by different energy facilities does not provide significant differences: the main type of fuel consumed in all three types of energy facilities under consideration is either coal or natural gas. The share of renewable energy sources is substantially lower in comparison to the share of traditional energy sources. 


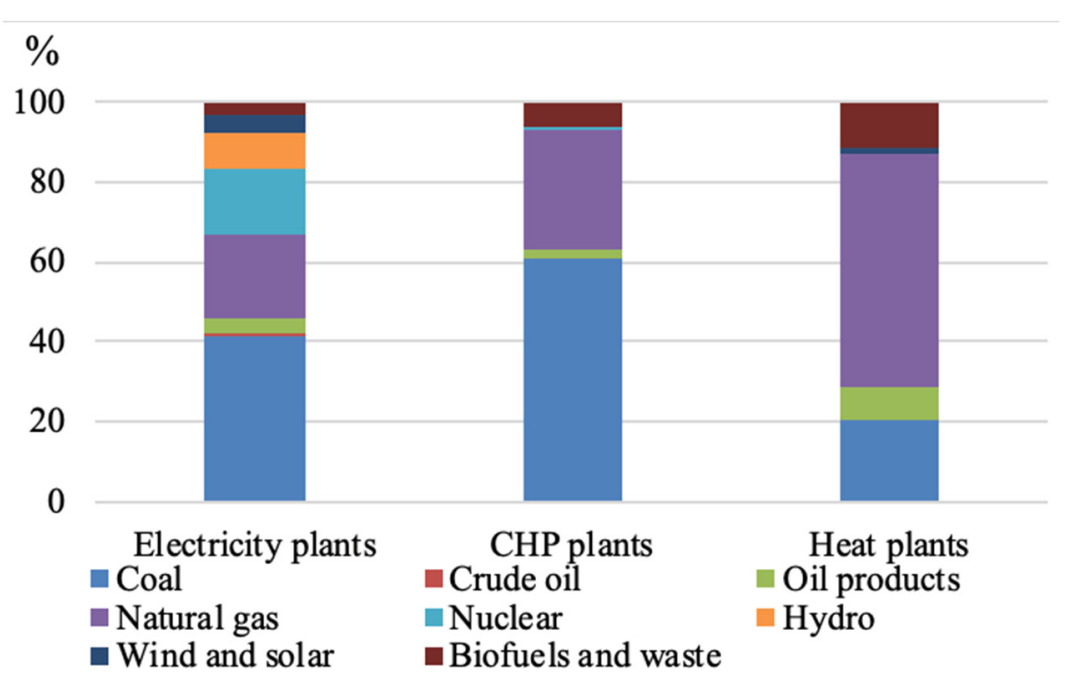

Figure 3: World fuel consumption structure of energy facilities in 2017. (Source: Calculated by the authors, using data from [14].)

The energy sector is also characterized by a significant amount of waste generation. The energy facilities that use coal as the main fuel (with or without addition of Solid Recovered Fuel) for energy production generate ash, that has a negative impact on the environment of the enterprise's location [19]-[21]. However, the generation of waste at energy facilities in OECD countries demonstrates a downward trend: the total generation of waste in the energy sector has been decreasing by $23.66 \%$ since 2004 , thanks also to the introduction of the Circular Economy concepts [3], [13], [22]. The share of the energy sector in total waste generation also declined from $5.46 \%$ to $3.51 \%$ (Fig. 4 ).

The energy sector is the largest consumer of water resources: in European Union the share of power plants in total freshwater consumption is $44 \%$ [23], in the USA its share is $41 \%$ [24]. Thus, the energy sector uses a significant amount of natural resources and produces large quantities of gaseous, liquid and solid waste.

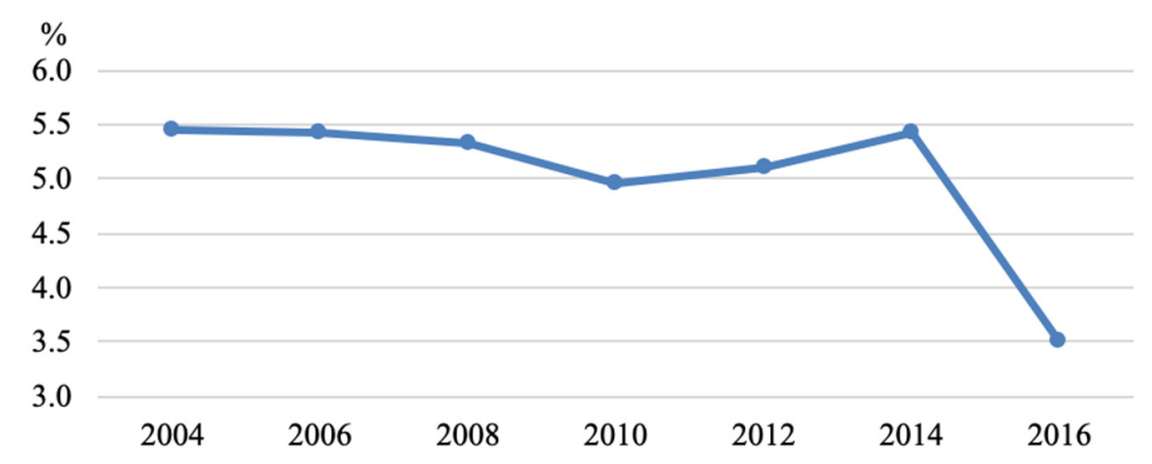

Figure 4: Energy sector's share in total generation of waste (OECD countries). (Source: Calculated by the authors using data from [22].) 
Evaluation of the economic efficiency of the investment projects has a significant role in the management of decision-making process [25], [26]. The traditional approach to the efficiency assessment of investment projects considers the financial and economic components. However, the environmental aspect of the project implementation should also be taken into account [27], since the approach to business development following the principle "grow now, clean up later" has led to serious negative environmental consequences [28]. At present, an efficiency assessment process should also include eco-efficiency assessment. The World Business Council of Sustainable Development (WBSCD) gives the following definition of eco-efficiency: "A management philosophy that encourages business to search for environmentally friendly solutions that yield simultaneous economic benefits, focusing on business opportunities and allowing companies to become more environmentally responsible and profitable, and is a key business contribution to sustainable societies" [29]. The most known method of eco-efficiency evaluation of investment projects is the "costeffectiveness" method. For this method, the indicator of efficiency is calculated as the ratio of environmental costs incurred to the economic effect of environmental activities. WBCSD also offers methods of eco-efficiency evaluation specified for various industries [29] which are labor-intensive and complex to implement. Accordingly, many companies are forced to neglect the use of these methods for project planning despite their consistency and scientific validity [30], [31].

Existing approaches to efficiency assessment of investment projects in the energy sector do not allow taking into account the positive and negative consequences, especially in terms of resource use [32]. One of the problems that arise in the environmental and economic assessment of investment projects is the incorrect display in quantitative indicators of the project's impact on the environment and the assessment of use of natural capital [33]. Reducing natural capacity is one of the directions of transition to eco-oriented sustainable development [34]. The purpose of this work is to develop improvements to the approach of the efficiency assessment of using natural resources in the energy sector.

\section{RESEARCH METHODS}

Indicators of resources capacity (by type of resource) and waste capacity might be considered as separate indicators of natural resources capacity. Such indicators of natural resources capacity as resources capacity and waste capacity of production are obtained by calculating the ratio of the amount of resources used, or the amount of waste generated to the corresponding production volume.

The analysis of natural resources capacity of investment projects in the energy sector suggests the efficiency assessment of exploitation of natural resources in the energy production.

In this paper, the natural resources capacity indicators of energy production, including resource capacity and waste capacity was proposed and used for the development of the research:

1. Resources capacity of energy production - a ratio of the resources used by energy facility (in physical units of measurement), to the corresponding amount of annual energy production (in physical units).

Fuel capacity and water capacity might be considered as indicators of resource capacity which characterize the use of certain kinds of natural resources. The calculations of fuel capacity and water capacity of energy production are determined by the eqn (1) and eqn (2), respectively 


$$
F=\frac{V_{\text {fuel }}}{N_{e}}
$$

where $F$ is the fuel capacity of energy production; $V_{\text {fuel }}$ is the fuel consumption by energy facility, in physical units; $N_{e}$ is the electrical energy produced by energy facility, in physical units

$$
A=\frac{V_{\text {water }}}{N_{e}}
$$

where $A$ is a water capacity of energy production, in physical units; $V_{\text {water }}$ is the water consumption by energy facility, in physical units.

2. Waste capacity of energy production $(W)$ - a ratio of waste generation within energy production to the corresponding amount of annual energy production (eqn (3))

$$
W=\frac{V_{w a s t e}}{N_{e}}
$$

where $W$ is the waste capacity of energy production, in physical units; $V_{\text {waste }}$ is the generation of waste by energy facility, in physical units.

The introduced criteria of natural capacity assessment of energy production allow one not only to qualitatively complement the method of project eco-efficiency assessment but also to compare alternative projects regarding the efficiency of the usage of natural resources and the amount of waste generated during the energy production.

The proposed approach will simplify the procedure of efficiency assessment of energy projects and the process of the management of decision-making regarding alternative investment projects.

Suggested indicators can be calculated in both physical and money units that will enhance the informational content of the analysis.

In addition, it is proposed to introduce an efficiency indicator that might be expressed by a generalized formula and used for efficiency assessment of investment projects at the energy sector (eqn (4))

$$
I=1-\frac{V_{2}}{V_{1}}
$$

where $I$ is the project's efficiency indicator; $V_{1,2}$ are the natural resources capacity indicators (fuel capacity, water capacity or waste capacity) before $\left(V_{1}\right)$ and after $\left(V_{2}\right)$ project implementation.

The decrease in the resource capacity and the waste capacity after the project implementation proves the effectiveness of the project regarding the use of natural sources. If the indicators show an upward trend, alternative projects must be considered.

To reach the positive outcome following the project implementation, the efficiency indicator ought to have a positive value and range from 0 to 1 - that will indicate the reduction of the natural resources capacity and rise in the resource effectiveness of the project. A negative value of efficiency indicator points to non-efficient resource use and the need to eliminate the project in favor of alternative ones.

The proposed system of indicators was tested on data of an investment project implemented on combined heat and power station (CHP) " $\mathrm{X}$ " located in the Ural Federal District, Russia. The purpose of the investment project is the modernization of energy facility through the transition to the gas and oil type of CHP. Before the project implementation, the CHP "X" used coal as the main type of fuel that led to the formation of harmful pollutants and its emissions to air. The implementation period is 2 years, the project implies the 
complete elimination of the coal infrastructure at the power plant within 2 years. Uninterrupted power supply should be provided by CHP " $\mathrm{X}$ " during the project's implementation.

\section{RESULTS AND DISCUSSION}

The initial eco-efficiency assessment of the project demonstrated its effectiveness as the switching from coal to natural gas resulted in a $47.01 \%$ decrease in waste generation and in a $10.45 \%$ decrease in the emission of pollutants to air. Emissions of lead and hydrogen chloride into the atmosphere were completely eliminated, dust emission was reduced by $93.6 \%$. The amount of produced energy increased by more than $7 \%$ (Table 1 ).

The fuel oil will continue to be used as a reserve fuel after project implementation. The trend is positive as the resource consumption has decreased. The calculation of natural capacity indicators before and after project implementation is provided in Table 2 .

Table 1: Main indicators of the CHP "X" before and after project implementation.

\begin{tabular}{|c|c|c|c|}
\hline Indicator & $\begin{array}{l}\text { 1st year } \\
\text { (before) }\end{array}$ & $\begin{array}{l}\text { 2nd year (project } \\
\text { implementation) }\end{array}$ & $\begin{array}{c}\text { 3rd year } \\
\text { (after) }\end{array}$ \\
\hline Energy production, $\mathrm{kWh}$ & 178,550 & 189,800 & 191,700 \\
\hline $\begin{array}{l}\text { Fuel consumption (total)*, tons/ } \\
\text { tons of fuel equivalent }\end{array}$ & $\begin{array}{l}539,220 / \\
387,520\end{array}$ & $\begin{array}{l}220,300 / \\
317,130\end{array}$ & $\begin{array}{l}224,500 / \\
323,520\end{array}$ \\
\hline $\begin{array}{l}\text { natural gas, } \mathrm{m}^{3} / \\
\text { tons/ } \\
\text { tons of fuel equivalent }\end{array}$ & $\begin{array}{l}121,900 / \\
97,500 / \\
140,670\end{array}$ & $\begin{array}{c}264,000 / \\
211,000 / \\
304,660 \\
\end{array}$ & $\begin{array}{l}275,000 / \\
220,000 / \\
317,350\end{array}$ \\
\hline $\begin{array}{l}\text { fuel oil, tons/ } \\
\text { tons of fuel equivalent }\end{array}$ & $\begin{array}{c}3,700 / \\
5,070 \\
\end{array}$ & $\begin{array}{l}9,100 / \\
12,470 \\
\end{array}$ & $\begin{array}{c}4,500 / \\
6,170 \\
\end{array}$ \\
\hline $\begin{array}{l}\text { coal, tons/ } \\
\text { tons of fuel equivalent }\end{array}$ & $\begin{array}{l}438,000 / \\
241,780 \\
\end{array}$ & 0 & 0 \\
\hline Water consumption, $\mathrm{m}^{3}$ & 175,280 & 154,920 & 149,180 \\
\hline Generation of waste, tons & 319,300 & 186,400 & 169,200 \\
\hline
\end{tabular}

*The following coefficients were used for converting tons and $\mathrm{m}^{3}$ to tons of fuel equivalent: natural gas $=1.154$; fuel oil $=1.37$; coal $=0.552$.

Table 2: Calculation of environmental indicators of the CHP " $\mathrm{X}$ " before and after project implementation.

\begin{tabular}{|l|c|c|c|c|}
\hline Environmental indicator & $\begin{array}{c}\text { 1st year } \\
\text { (before) }\end{array}$ & $\begin{array}{c}\text { 2nd year (project } \\
\text { implementation) }\end{array}$ & $\begin{array}{c}\text { 3rd year } \\
\text { (after) }\end{array}$ & $\begin{array}{c}\text { Efficiency } \\
\text { indicator 3rd } \\
\text { year/1st year }\end{array}$ \\
\hline $\begin{array}{l}\text { Fuel capacity of energy } \\
\text { production (total), tons of } \\
\text { fuel equivalent/kWh }\end{array}$ & 2.17 & 1.67 & 1.69 & 0.22 \\
\hline $\begin{array}{l}\text { Water capacity of energy } \\
\text { production, } \mathrm{m}^{3} / \mathrm{kWh}\end{array}$ & 0.98 & 0.82 & 0.78 & 0.20 \\
\hline $\begin{array}{l}\text { Waste capacity of energy } \\
\text { production, tons/kWh }\end{array}$ & 1.79 & 0.98 & 0.88 & 0.51 \\
\hline
\end{tabular}


The results of the analysis using the system of indicators proposed by the authors in the present paper, confirmed the effectiveness of eco-modernization project implemented at CHP "X".

According to the results, fuel capacity of energy production at CHP " $\mathrm{X}$ " decreased by $22 \%$ that indicates a high fuel efficiency of the project. The change in the structure of fuel consumption after the conversion to natural gas, as the main fuel type, and fuel oil, as the reserve fuel type, and the phase-out of coal significantly increase both resource and ecological efficiency of energy production at CHP "X". Fig. 5 demonstrates the change in the fuel capacity.

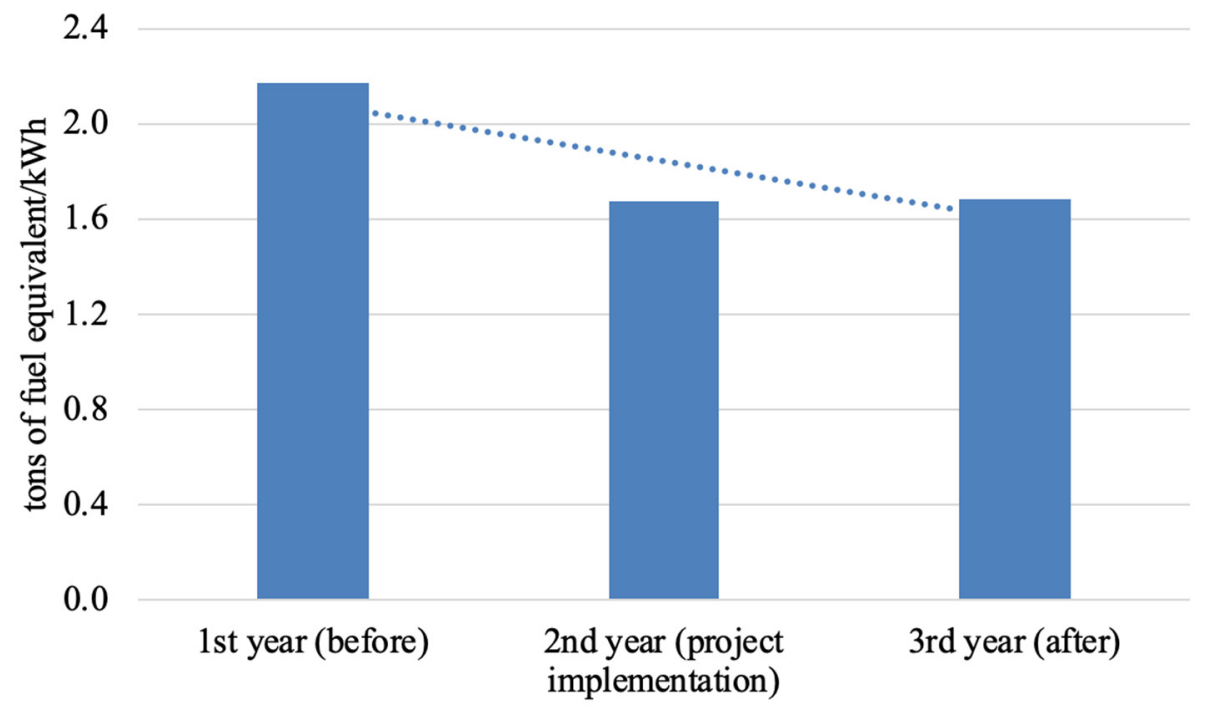

Figure 5: Change of fuel capacity on CHP "X" before and after project implementation.

Water capacity has shown a substantial decrease by $20 \%$ in the 3 rd year relative to its value in the 1 st year of the project implementation (Fig. 6).

The use of coal as a main fuel for CHP involves the formation of a significant amount of material waste, therefore, the transition to gas and oil fuel type of CHP reduced the generation of waste at the facility. Consequently, the calculated indicator of the waste capacity of energy production decreased.

The change of waste capacity of energy production before and after project implementation amounted to $51 \%$ (Fig. 7).

The proposed system of indicators enables us to take into account the natural resources capacity of energy production in the period of the investment project implementation and might be used for the assessment of economic and ecological efficiency of projects.

\section{CONCLUSION}

At present, the high efficiency of investment projects in the energy sector is determined not only by economic indicators but also environmental ones. Existing approaches do not allow providing a comprehensive assessment of the natural resources capacity of the investment 


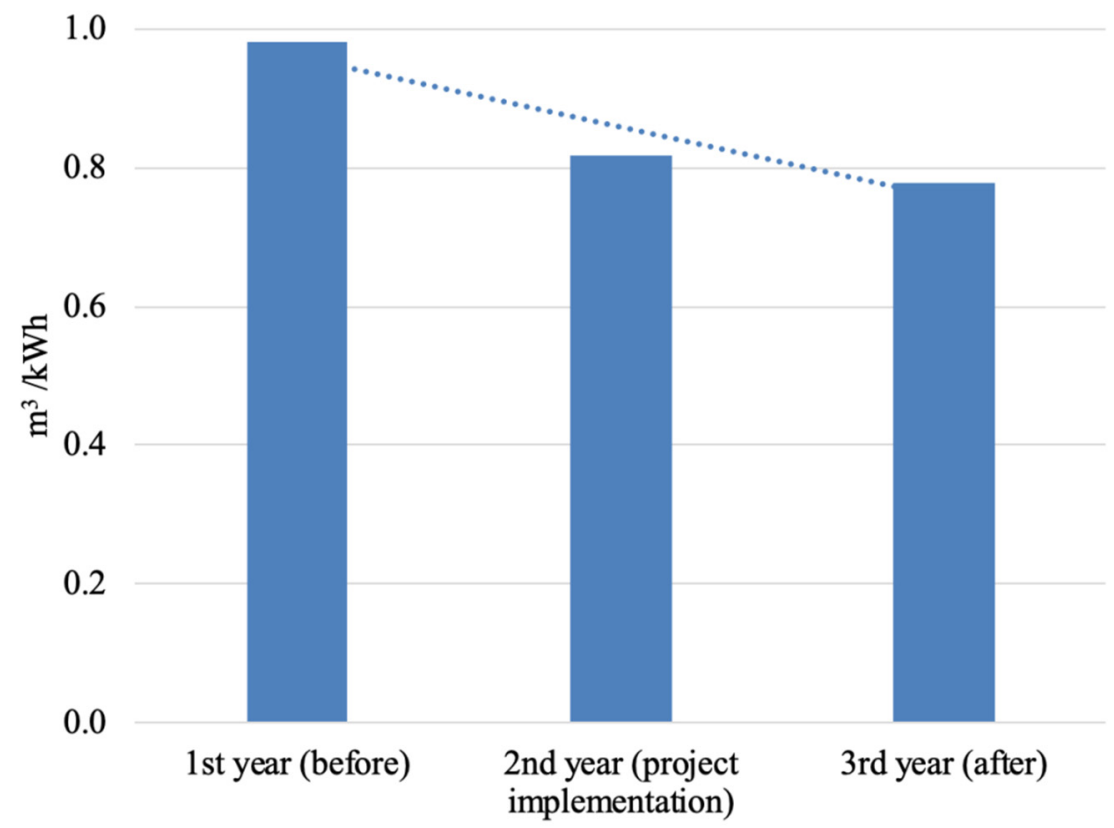

Figure 6: Change of water capacity on CHP "X" before and after project implementation.

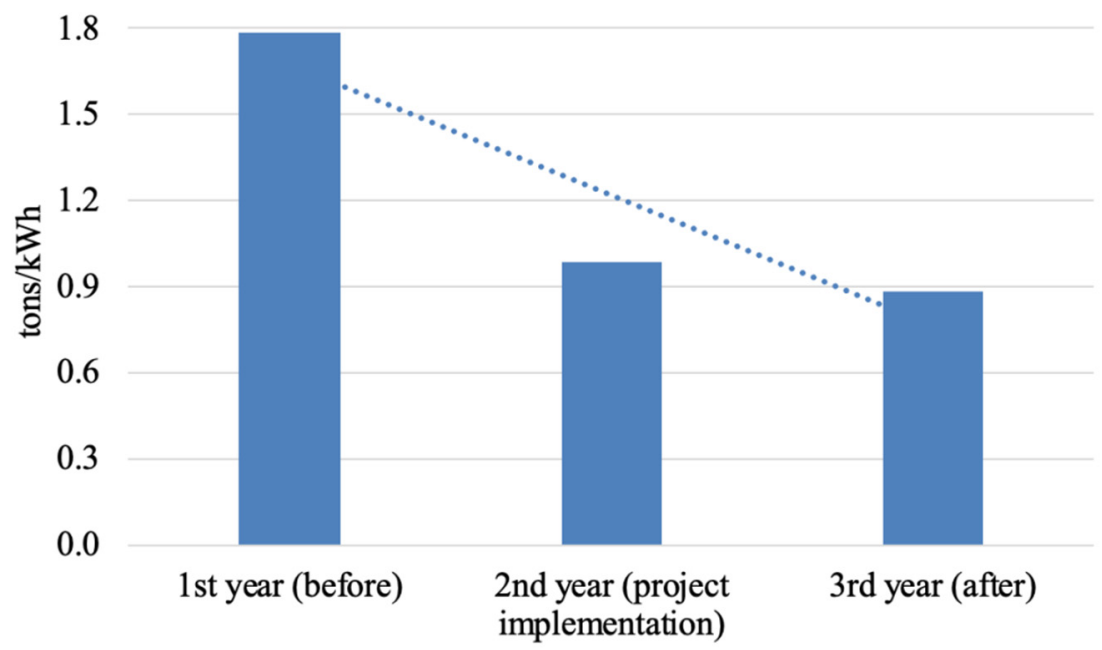

Figure 7: Change of waste capacity on CHP " $\mathrm{X}$ " before and after project implementation.

projects. The authors suggested the introduction of the natural resources capacity indicators of energy production. The introduced indicators provide an opportunity to simplify the efficiency assessment of the natural resources use within the implementation of an investment 
project in the energy sector. Results of validation of the proposed indicators led to the following conclusions:

- Natural resources capacity indicators might be used for comparison of alternative energy projects (including large and small ones);

- The system of indicators might be complemented by calculating natural resources capacity indicators in money units in order to raise informativeness and evaluate the efficiency of environmental measures from a commercial point of view;

- The suggested system of indicators needs further improvements and supplementation of the natural resources capacity indicators by the indicators of eco-efficiency assessment of the investment project.

Accordingly, supplemented with environmental impact indicators, the system will enable to provide a comprehensive environmental and economic assessment of the implementation of investment projects in the energy industry.

\section{ACKNOWLEDGEMENT}

This research was supported by Act 211 Government of the Russian Federation, contract number 02.A03.21.0006.

\section{REFERENCES}

[1] Kang, J.N., Wei, Y.M., Liu, L.C., Han, R., Yu, B.Y. \& Wang, J.W., Energy systems for climate change mitigation: A systematic review. Applied Energy, 263, 114602, 2020. https://doi.org/10.1016/j.apenergy.2020.114602.

[2] Ambrose, A., Walking with energy: Challenging energy invisibility and connecting citizens with energy futures through participatory research. Futures, 117, 102528. https://doi.org/10.1016/j.futures.2020.102528.

[3] Gitelman, L., Magaril, E., Kozhevnikov, M. \& Rada, E.C., Rational behavior of an enterprise in the energy market in a circular economy. Resources, 8(2), p. 73, 2019. https://doi.org/10.3390/resources8020073.

[4] Subramanian, A.S.R., Gundersen, T. \& Adams, T.A., Modeling and simulation of energy systems: A review. Processes, 6(12), p. 238, 2018. https://doi.org/10.3390/pr6120238.

[5] Petersen, S.A., Ahcin, P. \& Petersen, I., Smiling earth: Citizens' awareness on environmental sustainability using energy and transport data. Lecture Notes in Computer Science, 11863, pp. 459-465, 2019. https://doi.org/10.1007/978-3-030-34644-7_46.

[6] Liu, X., Yamamoto, R. \& Suk, S., A survey of company's awareness and approval of market-based instruments for energy saving in Japan. Journal of Cleaner Production, 78, pp. 35-47, 2014. https://doi.org/10.1016/j.jclepro.2014.05.005.

[7] Ionescu, R.D., Ragazzi, M., Battisti, L., Rada, E.C. \& Ionescu, G., Potential of electricity generation from renewable energy sources in standard domestic houses. WIT Transactions on Ecology and the Environment, Vol. 176, WIT Press: Southampton and Boston, pp. 245-253, 2013. https://doi.org/10.2495/ESUS130211.

[8] Akcura, E., Haney, A.B., Jamasb, T. \& Reiner, D.M., From citizen to consumer: Energy policy and public attitudes in the UK. The Future of Electricity Demand: Customers, Citizens and Loads, eds T. Jamasb \& M.G. Pollitt, Cambrige University Press: Cambridge, pp. 231-248, 2012. https://doi.org/10.1017/CBO9780511996191.015. 
[9] Muniyoor, K., Is there a trade-off between energy consumption and employment: Evidence from India. Journal of Cleaner Production, 255, 120262, 2020.

https://doi.org/10.1016/j.jclepro.2020.120262.

[10] Perkins, J.M. et al., Changes in socio-economic patterns of energy consumption and insufficient energy intake across India from 1993-1994 to 2011-2012. Public Health Nutrition, 23(2), pp. 231-242, 2020. https://doi.org/10.1017/S1368980019001484.

[11] Zhu, S., Song, M., Lim, M.K., Wang, J. \& Zhao, J., The development of energy blockchain and its implications for China's energy sector. Resources Policy, 66, 101595, 2020. https://doi.org/10.1016/j.resourpol.2020.101595.

[12] Zhou, C. \& Chen, X., Predicting energy consumption: A multiple decompositionensemble approach. Energy, 189, 116045, 2019. https://doi.org/10.1016/j.energy.2019.116045.

[13] BP Statistical Review of World Energy, www.bp.com/content/dam/bp/business-sites/ en/global/corporate/pdfs/energy-economics/statistical-review/bp-stats-review-2019full-report.pdf. Accessed on: 15 Feb. 2020.

[14] Energy Information Administration, Energy Consumption by Sector, Monthly Energy Review, February 2020. www.eia.gov/totalenergy/data/monthly/pdf/sec2_3.pdf. Accessed on: 20 Feb. 2020.

[15] Moustakas, K., Loizidou, M., Rehan, M. \& Nizami, A.S., A review of recent developments in renewable and sustainable energy systems: Key challenges and future perspective. Renewable and Sustainable Energy Reviews, 119, 109418, 2020. https://doi.org/10.1016/j.rser.2019.109418.

[16] Rada, E.C., Special waste valorization and renewable energy generation under a circular economy: Which priorities? WIT Transactions on Ecology and the Environment, Vol. 222, WIT Press: Southampton and Boston, pp. 145-157, 2019. https://doi.org/10.2495/EQ180141.

[17] Panepinto, D., Zanetti, M.C., Gitelman, L., Kozhevnikov, M., Magaril, E. \& Magaril, R., Energy from biomass for sustainable cities. IOP Conference Series: Earth and Environmental Science, 72(1), 012021, 2017. https://doi.org/10.1088/1755-1315/72/1/012021.

[18] Statistical Pocketbook EU Energy in Figures 2019. www.euneighbours.eu/sites/ default/files/publications/2019-09/MJAB19001ENN.en_.pdf. Accessed on: 21 Feb. 2020.

[19] Ruscio, A., Kazanc, F. \& Levendis, Y.A., Comparison of fine ash emissions generated from biomass and coal combustion and valuation of predictive furnace deposition indices: A review. Journal of Energy Engineering, 142(2), E4015007, 2016. https://doi.org/10.1061/(ASCE)EY.1943-7897.0000310.

[20] Rada, E.C., Squazardo, L., Ionescu, G. \& Badea, A., Economic viability of srf cocombustion in cement factory. UPB Scientific Bulletin, Series D: Mechanical Engineering, 76(3), pp. 199-206, 2014.

[21] Priyadarshini, P. \& Abhilash, P.C., Circular economy practices within energy and waste management sectors of India: A meta-analysis. Bioresource Technology, 304, 123018, 2020. https://doi.org/10.1016/j.biortech.2020.123018.

[22] European Environment Agency, Waste generation. www.themes.eea.europa.eu/ Sectorsandactivities/energy/indicators/EN13. Accessed on: 10 Feb. 2020.

[23] European Environment Agency, Trends and Projections in Europe 2019. www.eea.europa.eu/publications/trends-and-projections-in-europe-1. Accessed on: 10 Feb. 2020. 
[24] Dieter, C.A. et al., Estimated Use of Water in the United States County-Level Data for 2015, U.S. Geological Survey Circular, 2018. https://doi.org/10.3133/cir1441.

[25] Bartošová, V., Majerčák, P. \& Hrašková, D., Taking risk into account in the evaluation of economic efficiency of investment projects: Traditional methods. Procedia Economics and Finance, 24, pp. 68-75, 2015. https://doi.org/10.1016/S2212-5671(15)00614-0.

[26] Jiříček, P. \& Dvořáková, S., Solution of socio-economic efficiency of public projects under the conditions of variable amount of subsidy. Scientific Papers of the University of Pardubice, Series D: Faculty of Economics and Administration, 46(2), pp. 79-90, 2019.

[27] Azapagic, A. \& Perdan, S., Indicators of sustainable development for industry: A general framework. Process Safety and Environmental Protection, 78(4), pp. 243-261, 2000. https://doi.org/10.1205/095758200530763.

[28] ESCAP, Eco-efficiency indicators: Measuring resource-use efficiency and the impact of economic activities on the environment. Www.sustainabledevelopment.un.org/ content/documents/785eco.pdf. Accessed on: 22 Feb. 2020.

[29] World Business Council for Sustainable Development (WBCSD), Eco-efficiency. Creating more value with less impact, 2000.

[30] European Commission, Assessment of resource efficiency indicators and targets. https://ec.europa.eu/environment/enveco/resource_efficiency/pdf/annex_report.pdf. Accessed on: 22 Feb. 2020.

[31] Gotze, U., Pecas, P. \& Richter, F., Design for eco-efficiency: A system of indicators and their application to the case of mounds for injection moulding. Procedia Manufacturing, 33, pp. 304-311, 2019. https://doi.org/10.1016/j.promfg.2019.04.037.

[32] Hák, T., Janoušková, S. \& Moldan, B., Sustainable development goals: A need for relevant indicators. Ecological Indicators, 60, pp. 565-573, 2016. https://doi.org/10.1016/j.ecolind.2015.08.003.

[33] Aanand D., Ball, P. \& Salonitis, K., Factory eco-efficiency modelling: Data granularity and performance indicator. Procedia Manufacturing, 8, pp. 479-486, 2018. https://doi.org/10.1016/j.promfg.2017.02.061.

[34] Magaril, E.R, Abrzhina, L.L. \& Belyaeva, M.A., Environmental damage from the combustion of fuels: Challenges and methods of economic assessment. WIT Transactions on Ecology and The Environment, Vol. 190(2), pp. 1105-1115, 2014. https://doi.org/10.2495/EQ141032. 